\title{
PERAMALAN REALISASI PENERIMAAN ZAKAT PADA BAITULMAL ACEH DENGAN MEMPERTIMBANGKAN EFEK DARI VARIASI KALENDER
}

\author{
FORECASTING REALIZATION OF ZAKAT RECEIPTS AT \\ BAITUL MAL ACEH BY CONSIDERING EFFECTS OF \\ CALENDAR VARIATIONS
}

\author{
Rasyada Assakhiy ${ }^{1}$, Samsul Anwar ${ }^{1 *}$, Fitriana AR ${ }^{1}$ \\ ${ }^{1}$ Jurusan Statistika, FMIPA Universitas Syiah Kuala \\ samsul.anwar@unsyiah.ac.id
}

\begin{abstract}
Abstrak
Baitulmal Aceh merupakan sebuah lembaga pemerintah daerah Provinsi Aceh yang bertanggung jawab sebagai pengelola dan pendistribusi zakat, infak dan sedekah (ZIS). Peramalan potensi zakat pada masa yang akan datang dibutuhkan oleh Baitulmal Aceh sebagai salah satu landasan penyusunan kebijakan pengelolaan ZIS. Penelitian ini bertujuan untuk meramalkan potensi zakat yang terkumpul pada tahun 2018 dan 2019 dengan mempertimbangkan efek dari variasi kalender. Data yang digunakan dalam penelitian ini adalah data realisasi penerimaan zakat bulanan mulai dari bulan Januari 2015 hingga Desember 2017 yang diperoleh dari Baitulmal Aceh. Data tersebut dianalisis dengan model Autoregressive Integrated Moving Average with Exogenous Variable (ARIMAX) dan Seasonal Autoregressive Integrated Moving Average (SARIMA) sebagai model pembanding. Hasil penelitian menunjukkan bahwa model ARIMAX dengan orde $\operatorname{ARIMA}(2,0,2)(1,0,2)^{12}, \mathrm{t}, \mathrm{V}_{1}, \ldots, \mathrm{V}_{11}$ jauh lebih baik daripada model SARIMA dengan orde ARIMA $(0,1,2)(0,1,1)^{12}$ berdasarkan indikator ketepatan hasil ramalannya (RMSE dan MAPE). Realisasi penerimaan zakat pada tahun 2018 dan 2019 masing-masing diperkirakan sebesar Rp. 1.347.526.504 dan Rp. 1.359.728.268. Hasil peramalan tersebut dapat digunakan sebagai salah satu rujukan bagi Baitulmal Aceh dalam menyusun kebijakan pendistribusian zakat pada tahun-tahun yang akan datang.
\end{abstract}

Kata kunci: arimax, baitulmal aceh, peramalan zakat, sarima, variasi kalender

Klasifikasi JEL: C22, C32, C53, H24

\section{Abstract}

Baitul Mal Aceh is an Aceh provincial government institution that is responsible for managing and distributing zakat, infaq and shadaqah (ZIS). Forecasting the potential of zakat in the future is needed by the Baitul Mal Aceh as one of the foundations for the preparation of ZIS management policies. This study aims to predict the potential of zakat collected in 2018 and 2019 by considering effects of calendar variations. The data used in this study is data realization of monthly zakat receipts starting from January 2015 to December 2017 obtained from Baitul Mal Aceh. The data was analyzed using the Autoregressive Integrated Moving Average with Exogenous Variable (ARIMAX) and Seasonal Autoregressive Integrated Moving Average (SARIMA) as comparative model. The results showed that the ARIMAX model with order ARIMA $(2.0,2)(1,0,2)^{12}, t, V_{1}, \ldots, V_{11}$ is much better than the SARIMA model with order ARIMA $(0,1,2)(0,1,1)^{12}$ based on indicators of the prediction accuracy (RMSE and MAPE). Realization of zakat receipts in 2018 and 2019 are estimated in the amount of Rp. 1,347,526,504 and Rp. 1,359,728,268. The forecasting results can be used as one of the references for the Baitul Mal Aceh in preparing the policy of distributing zakat in the coming years.

Keywords: arimax, baitulmal aceh, zakat forecasting, sarima, calendar variations

JEL Classification: C22, C32, C53, H24 


\section{PENDAHULUAN}

Baitulmal wa Tamwil adalah sebuah badan yang bertugas untuk mengumpulkan serta membagikan dana sosial berupa zakat, infak dan sedekah (ZIS). Baitulmal wa Tamwil merupakan gabungan dari dua fungsi yaitu baitulmal yang dapat diartikan sebagai rumah dana dan baitul tamwil yang dapat diartikan sebagai badan bisnis keuangan yang berorientasikan laba (Mas'ud dan Muhamad, 2005). Pasca Tsunami tahun 2004 dan memorandum of understanding (MoU) Helsinki tahun 2005, Aceh mengalami transisi hukum dimana Undang-Undang No. 18/2001 tentang Otonomi Khusus bagi Provinsi Aceh dicabut dan diganti dengan Undang-Undang No. 11/2006 tentang Pemerintahan Aceh. Dalam undang-undang tersebut, pasal 191 dan 192 secara khusus mengatur tentang pengelolaan zakat di Provinsi Aceh yang dilakukan oleh lembaga Baitulmal Aceh.

Baitulmal Aceh berperan sangat penting dalam mengelola dan mendistribusikan zakat. Menurut Fitri (2017), tujuan pengelolaan zakat secara formal adalah untuk meningkatkan efektivitas dan efisiensi dalam pelayanan pengelolaan zakat serta untuk meningkatkan manfaat zakat dalam rangka mewujudkan kesejahteraan bagi masyarakat serta sebagai upaya dalam penanggulangan kemiskinan. Menurut Rodin (2015), terdapat dua langkah upaya pengentasan kemiskinan khususnya kaum fakir dan miskin, yaitu langkah yang bersifat struktural dan kultural. Langkah struktural lebih ditekankan kepada lembaga khusus misalnya baitulmal agar upaya tersebut dapat berjalan dengan baik, sedangkan langkah kultural lebih ditekankan pada level individu, baik yang diharapkan menjadi subjek pengentasan kemiskinan tersebut maupun yang menjadi objeknya.

Menurut Al-Qardhawi (2007), zakat adalah mengeluarkan sejumlah harta tertentu yang telah mencapai syarat (nishab) yang diwajibkan Allah SWT untuk dikeluarkan dan diberikan kepada yang berhak menerimanya dengan persyaratan tertentu. Informasi mengenai jumlah penerimaan zakat akan membantu Baitulmal Aceh dalam mengelola dan mendistribusikan zakat tersebut. Agar manajemen pengelolaan zakat dapat berjalan dengan baik, salah satunya diperlukan peramalan potensi zakat yang mungkin terkumpul pada masa yang akan datang.

Peramalan realisasi penerimaan zakat dapat berupa peramalan dalam jangka waktu bulanan maupun tahunan. Peramalan zakat dalam jangka waktu bulanan memiliki peranan penting karena permintaan informasi tentang penerimaan zakat tersebut akan semakin meningkat apabila dibandingkan dengan jangka waktu tahunan. Peramalan realisasi penerimaan zakat dalam jangka waktu bulanan juga harus mempertimbangkan unsur efek variasi kalender di dalam perhitungannya. Oleh karena itu, salah satu model peramalan yang dapat digunakan adalah model Autoregressive Integrated Moving Average with Exogenous Variable (ARIMAX). Selain itu, model Seasonal Autoregressive Integrated Moving Average (SARIMA) juga dapat diaplikasikan sebagai model pembanding dalam kasus ini.

Model ARIMAX merupakan modifikasi dari model dasar Autoregressive Integrated Moving Average (ARIMA) dengan penambahan variabel prediktor (exogenous). Pemodelan time series (runtun waktu) dengan menambahkan beberapa variabel lain akan memberikan pengaruh signifikan terhadap hasil peramalan variabel respon serta dapat meningkatkan tingkat akurasi peramalan yang dilakukan dalam suatu penelitian. Penelitian yang menggunakan model ARIMAX dengan mempertimbangkan efek dari variasi kalender pernah dilakukan oleh Lee et al. (2010) yang meneliti pengaruh efek hari raya idul fitri terhadap penjualan baju muslim laki-laki dan Anggraeni et al. (2015) yang meneliti pengaruh efek hari raya idul fitri terhadap penjualan baju muslim anak-anak di kota Surabaya. Kedua penelitian tersebut menggunakan variabel dummy berupa waktu pelaksanaan hari raya idul fitri sebagai variabel prediktor. Penggunaan model ARIMAX dengan variasi kalender pada kedua penelitian tersebut terbukti dapat meningkatkan akurasi peramalan dibandingkan dengan model time series lainnya. Berdasarkan uraian latar belakang di atas, maka penelitian ini bertujuan untuk meramalkan realisasi penerimaan zakat Baitulmal Aceh dalam periode bulanan pada tahun 2018 dan 2019 dengan menggunakan model ARIMAX yang memasukkan efek dari variasi 
kalender serta dengan menggunakan model SARIMA sebagai model pembanding.

\section{TINJAUAN PUSTAKA}

Menurut Cryer dan Chan (2008) variabel time series adalah variabel yang disusun berdasarkan urutan waktu atau variabel yang dikumpulkan dari kurun waktu ke waktu. Waktu yang digunakan dapat berupa harian, minggu, bulan, tahun, maupun ukuran waktu lainnya. Variabel time series merupakan serangkaian variabel pengamatan yang berasal dari satu sumber tetap dan terjadi berdasarkan indeks waktu secara beruntun dengan interval waktu yang tetap. Wei (2006) berpendapat bahwa setiap pengamatan tersebut dapat dinyatakan sebagai variabel acak (random) dengan notasi .

Salah satu konsep penting dalam time series adalah stasioner. Menurut Makridakis et al. (2000), stasioner merupakan suatu keadaan dimana tidak terjadinya kenaikan atau penurunan dalam data. Fluktuasi data tersebut berada di sekitar nilai rata-rata secara konstan dan tidak tergantung pada waktu serta memiliki varian yang konstan. Menurut Wei (2006), stasioner dibagi menjadi 2 yaitu stasioner dalam variansi dan stasioner dalam rata-rata. Stasioner dalam variansi terjadi apabila variabel dari kurun waktu ke waktu mempunyai fluktuasi yang tetap (konstan) serta tidak berubah-ubah. Adapun cara untuk mengetahui stasioner dalam variansi adalah dengan cara mendeteksinya dengan menggunakan nilai Box Cox. Menurut Box dan Cox (1964), variabel akan stasioner dalam varian apabila nilai . Apabila nilai maka dapat dikatakan variabel tersebut tidak stasioner dalam variansi. Hal tersebut dapat diatasi dengan cara melakukan transformasi kuasa (power transformation). Sedangkan, stasioner dalam rata-rata merupakan situasi dimana fluktuasi variabel berada di sekitar nilai rata-rata yang konstan, tidak bergantung pada waktu dan variansi dari fluktuasi variabel tersebut (Wei, 2006). Stasioner dalam rata-rata dapat diuji dengan menggunakan uji Augmented Dickey-Fuller (ADF). Variabel yang digunakan sudah stasioner atau tidak mengandung akar unit apabila uji ADF memiliki $p$-value $<(0,05)$.

\section{Efek Variasi Kalender}

Menurut Cleveland dan Devlin (1982)day-ofthe-week effects, and holidays. It is important to remove the calendar variation to allow an effective assessment of the variation due to important factors. New procedures for calendar adjustment are presented in this article. A plausible model for the daily data is used to derive a model for the monthly data in which the power transformed, month-length corrected data are equal to trend plus seasonal plus calendar plus irregular. The procedure for fitting the calendar component in the monthly model is (a, sebagian besar data time series bulanan yang mewakili beberapa variabel dalam setiap bulannya mengandung efek kalender karena adanya perubahan panjang atau lama bulan, efek hari cuti - minggu, dan hari liburan. Penelitian yang dilakukan oleh Liu (1980) menunjukkan bahwa intervensi variasi kalender mempengaruhi nilai autokorelasi sampel baik secara teoritis maupun dengan menggunakan data empiris. Menurut Liu (2009), variasi kalender pada data time series terdiri atas dua jenis yaitu variasi liburan yang disebabkan oleh kebiasaan konsumen yang dipengaruhi hari libur dan variasi perdagangan yang dipengaruhi oleh aktivitas bisnis atau kegiatan usaha dan tingkat ekonomi. Variasi tersebut disebabkan oleh adanya perbedaan jumlah hari dalam setiap bulannya maupun setiap tahunnya yang terkait dengan aktivitas liburan dan perdagangan. Menurut Lee et al. (2010), efek dari variasi kalender tersebut dapat dihilangkan dengan melakukan regresi variabel dummy dengan tren stokastik dan tren deterministik terhadap variabel respon yang dianalisis.

\section{Model Dasar Time Series}

Klasifikasi model dasar time series pada domain waktu dibagi ke dalam tiga kelompok, yaitu model autoregressive (AR), moving average (MA), dan model campuran (ARMA dan ARIMA) yang mempunyai karakteristik dari dua model pertama.

\section{Model Autoregressive (AR)}

Menurut Montgomery et al. (2008), bentuk umum model Autoregressive dengan orde dinotasikan dapat dituliskan dalam persamaan berikut: 


$$
\Phi(B) Y_{t}=\delta+\Theta(B) \varepsilon_{t}
$$

2. Model Moving Average (MA)

Menurut Montgomery et al. (2008), model moving average dengan orde dinotasikan dapat dituliskan dalam persamaan berikut:

$$
\Phi(B) Y_{t}=\delta+\varepsilon_{t}
$$

3. Model Campuran

Terdapat 2 model campuran yaitu:

1) Model Autoregressive Moving Average (ARMA)

Menurut Montgomery et al. (2008), bentuk umum model Autoregressive Moving Average dengan notasi dapat dituliskan sebagai berikut:

$\Phi(B) Y_{t}=\delta+\Theta(B) \varepsilon_{t}$

2) Model Autoregressive Integrated Moving Average (ARIMA)

Menurut Montgomery et al. (2008), ARIMA dapat digunakan apabila variabel yang digunakan tidak stasioner pada rata-rata, sehingga harus dilakukan differencing terlebih dahulu. Bentuk umum model Autoregressive Integrated Moving Average dengan notasi dapat dituliskan dalam persamaan berikut:

$$
\Phi(B)(1-B)^{d} Y_{t}=\delta+\Theta(B) \varepsilon_{t}
$$

dengan:

$\delta \quad:$ intercept

$Y_{t} \quad$ nilai variabel respon pada waktu ke- $t$

$(1-B)^{d}:$ integrated

$\Phi(B) \quad:$ parameter autoregressive $\left(1-\phi_{1} B-\cdots-\phi_{p} B^{p}\right)$

$\Theta(B) \quad:$ parameter moving average $\left(1-\theta_{1} B-\cdots-\theta_{q} B^{q}\right)$

$\varepsilon_{t} \quad:$ nilai kesalahan pada waktu ke- $t$

\section{Identifikasi Model Dasar Time Series melalui Plot ACF dan PACF}

Menurut Wei (2006), alat utama untuk mengidentifikasi model dari suatu variabel time series yang akan diramalkan adalah dengan menggunakan fungsi autokorelasi atau Autocorrelation Function (ACF) dan fungsi autokorelasi parsial atau Partial Autocorrelation Function (PACF). Secara umum, identifikasi model dasar time series yang terdiri dari model autoregressive (AR), moving average (MA), dan model campuran (ARMA dan ARIMA) dapat dilakukan dengan menggunakan aturan pada

\begin{tabular}{|c|c|c|}
\hline No & ACF dan PACF Plot & Model \\
\hline \multirow[t]{2}{*}{1} & ACF signifikan pada lag $1,2, \ldots, q$ dan terpotong pada lag $q$ & $\mathrm{MA}(\mathrm{q})$ \\
\hline & PACF menurun secara eksponensial & \\
\hline \multirow[t]{2}{*}{2} & ACF menurun secara eksponensial & $\mathrm{AR}(\mathrm{p})$ \\
\hline & PACF signifikan pada lag $1,2, \ldots, p$ dan terpotong setelah lag $p$ & \\
\hline \multirow[t]{2}{*}{3} & ACF signifikan pada lag $1,2, \ldots, q$ dan terpotong setelah lag $q$ & $\operatorname{ARMA}(\mathrm{p}, \mathrm{q})$ \\
\hline & PACF signifikan pada lag $1,2, \ldots, p$ dan terpotong setelah lag $p$ & \\
\hline 4 & Tidak ada autokorelasi yang signifikan dalam ACF dan PACF plot & $\operatorname{ARMA}(0,0)$ \\
\hline \multirow[t]{3}{*}{5} & ACF signifikan pada lag $1,2, \ldots, q$ dan terpotong pada lag $q$ & \\
\hline & Difference ke $d$ & $\operatorname{IMA}(\mathrm{d}, \mathrm{q})$ \\
\hline & PACF menurun secara eksponensial & \\
\hline \multirow[t]{3}{*}{6} & ACF menurun secara eksponensial & \\
\hline & Difference ke $d$ & $\operatorname{ARI}(\mathrm{p}, \mathrm{d})$ \\
\hline & PACF signifikan pada lag $1,2, \ldots, p$ dan terpotong setelah lag $p$ & \\
\hline \multirow[t]{3}{*}{7} & ACF signifikan pada lag $1,2, \ldots, q$ dan terpotong setelah lag $q$ & \\
\hline & Difference ke $d$ & $\operatorname{ARIMA}(\mathrm{p}, \mathrm{d}, \mathrm{q})$ \\
\hline & PACF signifikan pada lag $1,2, \ldots, p$ dan terpotong setelah lag $p$ & \\
\hline \multirow[t]{2}{*}{8} & Tidak ada autokorelasi yang signifikan dalam ACF dan PACF plot & $\operatorname{ARIMA}(0, \mathrm{~d}, 0)$ \\
\hline & Difference ke $d$ & \\
\hline
\end{tabular}
Tabel 1 (Anwar, 2017).

Tabel 1. Identifikasi Model Time Series dengan Plot ACF dan PACF

Keterangan: model ARIMAX dan SARIMA merupakan model turunan atau perluasan dari model dasar time series 


\section{Model ARIMAX}

Menurut Cryer dan Chan (2008), model ARIMAX merupakan perluasan model ARIMA dengan penambahan variabel tertentu. Penambahan variabel tersebut berfungsi untuk meningkatkan tingkat keakuratan hasil peramalan (Kongcharoen dan Kruangpradit, 2013). Menurut Andrews, Dean, Swain, dan Cole (2013), model ARIMAX mempunyai kapasitas untuk mengidentifikasi pola tersembunyi dalam data time series. Lebih lanjut, Andrews et al. (2013) menyatakan bahwa pemodelan ARIMAX dapat disederhanakan menjadi pemodelan ARIMA apabila ingin digunakan untuk memeriksa perilaku historis dan melakukan peramalan dengan hanya menggunakan pola historis yang diidentifikasi secara statistik.

Model ARIMAX dapat dituliskan dalam persamaan berikut (Cryer dan Chan, 2008):

$Y_{t}=\beta_{0}+\beta_{1} V_{t-d}+Z_{t}$

dimana $Z_{t}$ mengikuti model $\operatorname{ARIMA}(p, d, q)$.

Secara sederhana, model ARIMAX juga dapat dilihat sebagai model regresi berganda dengan satu atau lebih komponen AR dan MA. Komponen AR untuk variabel respon adalah nilai lag dari variabel respon tersebut yang memiliki hubungan yang signifikan dengan nilai terbarunya, sedangkan komponen MA adalah nilai residual $(\varepsilon)$ yang dihasilkan dari estimasi yang telah dibuat sebelumnya (Andrews et al., 2013).

Menurut Hyndman dan Athanasopoulos (2018), terdapat dua cara yang berbeda dalam memodelkan tren linier yakni tren stokastik dan tren deterministik. Tren stokastik diperoleh dari model sebagai berikut:

$Y_{t}=\beta_{0}+\beta_{1} t+\eta_{t}$

Dimana adalah proses ARIMA dengan . Sedangkan tren deterministik diperoleh dengan menggunakan model regresi pada persamaan (6) dengan adalah proses ARMA. Berikut model ARIMAX dengan model tren stokastik dan tren deterministik untuk efek variasi kalender bulanan:

1. Model dengan Tren Stokastik

Menurut Lee et al. (2010), model ARIMAX dengan tren stokastik (difference on non-seasonal or seasonal) dapat dituliskan sebagai berikut:

$$
\begin{aligned}
& Y_{t}=\beta_{1} V_{1, t}+\beta_{2} V_{2, t}+\cdots+\beta_{p} V_{p, t}+ \\
& \frac{\theta_{q}(B) \Theta_{Q}\left(B^{S}\right)}{\phi_{p}(B) \Phi_{P}\left(B^{S}\right)(1-B)^{d}\left(1-B^{S}\right)^{D}} \varepsilon_{t}
\end{aligned}
$$

\section{Model dengan Tren Deterministik}

Menurut Lee et al. (2010), model ARIMAX dengan tren deterministik tanpa proses difference dapat dituliskan sebagai berikut:

$$
\begin{aligned}
& Y_{t}=\gamma t+\beta_{1} V_{1, t}+\beta_{2} V_{2, t}+\cdots+ \\
& \beta_{p} V_{p, t}+\frac{\theta_{q}(B) \Theta_{Q}\left(B^{S}\right)}{\phi_{p}(B) \Phi_{P}\left(B^{S}\right)^{D}} \varepsilon_{t}
\end{aligned}
$$

dengan $V_{1, t}$ hingga $V_{p, t}$ merupakan variabel dummy (bernilai 0 atau 1) yang menangkap efek variasi kalender bulanan dan merupakan koefisien yang menangkap adanya efek tren.

\section{Model SARIMA}

Menurut Montgomery et al. (2008), beberapa variabel time series menunjukkan adanya pola periodik yang kuat. Hal ini sering disebut sebagai time series yang memiliki sifat musiman. Time series dengan sifat musiman terutama terjadi ketika variabel yang diambil lebih spesifik dalam interval bulanan, mingguan, dan sebagainya. Time series yang memiliki perilaku musiman sering disebut juga dengan seasonal ARIMA atau SARIMA. Dengan demikian, model SARIMA merupakan perluasan dari model dasar ARIMA. Berikut persamaan Seasonal ARIMA dengan notasi menggunakan periode sebagai berikut:

$\phi_{p}\left(B^{s}\right) \Phi_{P}(B)(1-B)^{d}\left(1-B^{s}\right)^{D} Y_{t}=\delta+\Theta_{Q}\left(B^{s}\right) \theta_{q}(B) \varepsilon_{t}$ dengan:

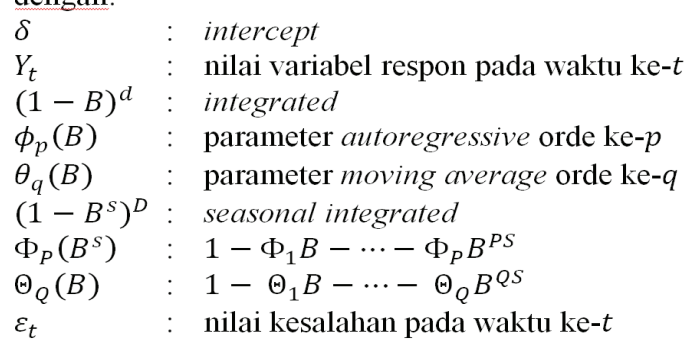

\section{Pengujian Diagnostik Parameter Model}

Menurut Cryer dan Chan (2008), komponen stokastik yang tidak teramati dapat diperkirakan atau diprediksi dengan residual $(\varepsilon)$ melalui persamaan sebagai berikut: 
$\varepsilon_{t}=Y_{t}-\hat{Y}_{t}$

Dimana $\varepsilon_{t}$ merupakan residual untuk pengamatan ke-, $Y_{t}$ merupakan pengamatan kedan merupakan nilai peramalan pada pengamatan ke-. Beberapa asumsi tentang komponen stokastik dapat dinilai dengan cara melihat residual. Apabila komponen stokastik bersifat white noise, maka residual harus bersifat seperti variabel acak (normal) dengan rata-rata 0 dan varian $\sigma^{2}$. Menurut Wei (2006), untuk mengetahui apakah autokorelasi antar residual telah mengikuti proses white noise atau tidak maka dilakukan pengujian pada residual melalui nilai autokorelasinya. Hal tersebut dilakukan melalui uji kecocokan model Ljung-Box-Pierce. Residual dari model dikatakan tidak memiliki autokorelasi atau telah memenuhi asumsi white noise apabila uji Ljung-Box-Pierce memiliki $p$-value $>\alpha(0,05)$.

\section{Pemilihan Model Terbaik}

Menurut Wei (2006), terdapat beberapa kemungkinan model yang sesuai dalam permodelan variabel time series, yaitu model yang memiliki nilai kesalahan/residual yang kecil. Oleh karena itu, diperlukan indikator terukur yang dapat digunakan untuk memilih sebuah model terbaik dari beberapa model yang tersedia. Dua indikator yang sering digunakan dalam pemodelan time series adalah Root Mean Square Error (RMSE) dan Mean Absolute Percentage Error (MAPE) dengan persamaan sebagai berikut:

$$
\begin{aligned}
& R M S E=\sqrt{\frac{\sum_{t=1}^{n}\left(Y_{t}-\hat{Y}_{t}\right)^{2}}{n}} \\
& M A P E=\sum_{t=1}^{n} \frac{\left|Y_{t}-\hat{Y}_{t}\right|}{n} \times 100 \%
\end{aligned}
$$

dimana:

$$
\begin{array}{ll}
Y_{t} & : \begin{array}{l}
\text { variabel respon pada periode ke- } t \\
Y_{t}
\end{array} \\
n & : \text { nilai peramalan pada periode ke- } t \\
& \text { jumlah data/ pengamatan }
\end{array}
$$

\section{Baitulmal Aceh}

Baitulmal Aceh merupakan sebuah lembaga pengelolaan zakat tingkat provinsi yang terbentuk sejak bulan April 1973 dengan nama Badan Penertiban Harta Agama (BPHA). BPHA dibentuk berdasarkan Surat Keputusan Gubernur Provinsi Aceh Nomor 05/1973. Nama lembaga ini kemudian mengalami beberapa kali perubahan, yaitu pada Januari 1975 menjadi Badan Harta Agama (BHA), pada Februari 1993 menjadi BAZIZ/BASDA, pada Januari 2004 menjadi Badan Baitulmal, dan terakhir pada Januari 2008 menjadi Baitulmal Aceh berdasarkan Qanun Aceh Nomor 10 Tahun 2007.

Adapun fungsi dan kewenangan Baitulmal Aceh tercantum dalam Qanun Nomor 10 Tahun 2007 Pasal 8 Ayat 1 sebagai berikut:

1. Mengurus dan mengelola zakat, wakaf, dan harta agama.

2. Melakukan pengumpulan, penyaluran dan pendayagunaan zakat.

3. Melakukan sosialisasi zakat, wakaf, dan harta agama lainnya.

4. Menjadi wali terhadap anak yang tidak mempunyai lagi wali nasab, wali pengawas terhadap wali nasab, dan wali pengampu terhadap orang dewasa yang tidak cakap melakukan perbuatan hukum.

5. Menjadi pengelola terhadap harta yang tidak diketahui pemilik atau ahli warisnya berdasarkan putusan Mahkamah Syariah.

6. Membuat perjanjian kerjasama dengan pihak ketiga untuk meningkatkan pemberdayaan ekonomi umat berdasarkan prinsip saling menguntungkan.

\section{METODE PENELITIAN}

Penelitian ini dilakukan di Jurusan Statistika, Fakultas Matematika dan Ilmu Pengetahuan Alam (FMIPA), Universitas Syiah Kuala. Data yang digunakan dalam penelitian ini adalah data sekunder yaitu data realisasi penerimaan zakat periode bulanan dengan jumlah data sebanyak 36 data, mulai dari bulan Januari 2015 hingga Desember 2017 yang diperoleh dari Baitulmal Provinsi Aceh. Penelitian ini menggunakan model time series yang mempertimbangkan efek dari variasi kalender yaitu model ARIMAX untuk meramalkan realisasi penerimaan zakat pada Baitulmal Aceh. Selain itu, model SARIMA juga digunakan sebagai model pembanding dalam meramalkan realisasi penerimaan zakat pada Baitulmal Aceh tersebut. Pengolahan data dilakukan dengan menggunakan software $R$ versi 3.3.1 dan Microsoft Excel 2013. Adapun definisi operasional variabel yang digunakan 
dalam penelitian ini dapat dilihat pada Tabel 2 berikut ini.

Tabel 2. Variabel Penelitian

\begin{tabular}{llll}
\hline Variabel & Keterangan & $\begin{array}{l}\text { Tipe } \\
\text { Data }\end{array}$ & Kategori \\
\hline \multirow{2}{*}{ Respon () } & $\begin{array}{l}\text { Realisasi } \\
\text { penerimaan } \\
\text { zakat (Rupiah) }\end{array}$ & Rasio & - \\
& &
\end{tabular}

Proses analisis data yang dilakukan dalam penelitian adalah sebagai berikut.

A. Peramalan dengan Model ARIMAX.

Adapun langkah-langkah dalam peramalan dengan model ARIMAX adalah sebagai berikut:

1. menentukan dan melakukan regresi variabel dummy $(V)$ dengan tren stokastik dan tren deterministik untuk menghilangkan efek variasi kalender dari variabel respon.

$Y_{t}=\beta_{0}+\beta_{1} V_{1, t}+\beta_{2} V_{2, t}+\cdots+\beta_{p} V_{p, t}+w_{t}$

Persamaan regresi variabel dummy untuk tren stokastik adalah sebagai berikut:

$$
\begin{aligned}
Y_{t}= & \beta_{0}+\gamma t+\beta_{1} V_{1, t}+\beta_{2} V_{2, t}+\cdots+\beta_{p} V_{p, t} \\
& +w_{t}
\end{aligned}
$$

Persamaan regresi variabel dummy untuk tren deterministik adalah sebagai berikut:

2. memodelkan residual hasil regresi model respon variabel dummy dengan model ARIMA.

Adapun langkah-langkah dalam model ARIMA adalah sebagai berikut:

2.1. memeriksa apakah data residual hasil regresi variabel dummy sudah stasioner terhadap varian maupun mean,

2.2. melakukan proses transformasi apabila data residual tidak stasioner terhadap varian dan proses differencing apabila data residual tidak stasioner terhadap mean,

2.3. identifikasi model yang akan digunakan dengan melihat plot ACF dan PACF,
2.4. melakukan pemeriksaan signifikansi parameter dan residual hingga proses stasioner dan residual memenuhi asumsi white noise, dan

2.5. melakukan pemilihan model terbaik dengan menggunakan kriteria nilai RMSE dan MAPE terkecil.

3. menggunakan orde model ARIMA data residual pada langkah 3 untuk memodelkan variabel respon dengan menggunakan model ARIMAX:

3.1. melakukan pemeriksaan pola musiman dan diagnostik parameter model ARIMAX,3.2 melakukan pemilihan model ARIMAX terbaik dengan menggunakan kriteria nilai RMSE dan MAPE yang terkecil.

B. Peramalan dengan Model SARIMA.

Adapun langkah-langkah dalam peramalan dengan model SARIMA adalah sebagai berikut:

1. memeriksa apakah variabel respon sudah stasioner terhadap varian maupun mean,

2. melakukan identifikasi model ARIMA yang akan digunakan dengan melihat plot ACF dan PACF,melakukan pengujian diagnostik parameter model ARIMA,melakukan pemilihan model ARIMA terbaik dengan menggunakan kriteria nilai RMSE dan MAPE terkecil,melakukan pemeriksaan pola musiman dan identifikasi model SARIMA,melakukan pengujian diagnostik parameter model SARIMA, danmelakukan pemilihan model SARIMA terbaik dengan menggunakan kriteria nilai RMSE dan MAPE terkecil.

C. Peramalan Realisasi Penerimaan Zakat pada Baitulmal Aceh Tahun 2018 dan 2019.

\section{HASIL DAN PEMBAHASAN}

\section{Analisis deskriptif}

Analisis deskriptif dari data realisasi penerimaan zakat pada Baitulmal Aceh tahun 2015 hingga 2017 disajikan pada Tabel 3. 
Tabel 3. Statistik Deskriptif

\begin{tabular}{ccccc}
\hline Tahun & Minimum & Rata-rata & Maksimum & Total \\
2015 & 16.317 .179 & 86.685 .771 & 322.869 .965 & 1.040 .229 .257 \\
2016 & 30.659 .223 & 73.975 .619 & 229.962 .378 & 887.707 .429 \\
2017 & 21.269 .016 & 77.541 .748 & 357.845 .039 & 930.500 .971 \\
\hline
\end{tabular}

Sumber: Baitulmal Aceh (2018), diolah.

Tabel 3 menunjukkan bahwa total realisasi penerimaan zakat Baitulmal Aceh pada tahun 2015 hingga 2017 adalah sebesar Rp. 2.858.437.657. Meskipun terjadi penurunan jumlah penerimaan zakat pada tahun 2016, namun jumlah penerimaan zakat tersebut kembali meningkat pada tahun berikutnya. Semua nilai statistik deskriptif pada Tabel 3 menunjukkan bahwa 2015 merupakan tahun dengan realisasi penerimaan zakat terbaik dalam kurun waktu tiga tahun tersebut.

Secara umum, terdapat 3 pokok pembahasan pada bagian ini, yaitu penerapan model ARIMAX, penerapan model SARIMA dan peramalan realisasi penerimaan zakat Baitulmal Aceh Tahun 2018 dan 2019.

\section{A. Peramalan Dengan Model ARIMAX}

Proses peramalan dengan model ARIMAX meliputi langkah-langkah sebagai berikut.

1. Menentukan dan melakukan regresi variabel dummy

Regresi variabel dummy untuk variasi kalender dilakukan untuk mendapatkan residual dari model regresi. Adapun variabel dummy yang digunakan pada penelitian ini dapat dilihat pada Tabel 4.

Tabel 4. Variabel Dummy untuk Variasi Kalender

\begin{tabular}{llll}
\hline \multicolumn{1}{c}{ Bulan } & \multicolumn{1}{c}{ Variabel Dummy } & \multicolumn{1}{c}{ Bulan } & \multicolumn{1}{c}{ Variabel Dummy } \\
\hline Januari $\left(\mathrm{V}_{1}\right)$ & $1,0,0,0,0,0,0,0,0,0,0$ & Juli $\left(\mathrm{V}_{7}\right)$ & $0,0,0,0,0,0,1,0,0,0,0$ \\
Februari $\left(\mathrm{V}_{2}\right)$ & $0,1,0,0,0,0,0,0,0,0,0$ & Agustus $\left(\mathrm{V}_{8}\right)$ & $0,0,0,0,0,0,0,1,0,0,0$ \\
Maret $\left(\mathrm{V}_{3}\right)$ & $0,0,1,0,0,0,0,0,0,0,0$ & September $\left(\mathrm{V}_{9}\right)$ & $0,0,0,0,0,0,0,0,1,0,0$ \\
April $\left(\mathrm{V}_{4}\right)$ & $0,0,0,1,0,0,0,0,0,0,0$ & Oktober $\left(\mathrm{V}_{10}\right)$ & $0,0,0,0,0,0,0,0,0,1,0$ \\
Mei $\left(\mathrm{V}_{5}\right)$ & $0,0,0,0,1,0,0,0,0,0,0$ & November $\left(\mathrm{V}_{11}\right)$ & $0,0,0,0,0,0,0,0,0,0,1$ \\
Juni $\left(\mathrm{V}_{6}\right)$ & $0,0,0,0,0,1,0,0,0,0,0$ & & \\
& & & \\
\hline
\end{tabular}

Keterangan: Bulan Desember sebagai reference kategori

Penelitian ini menggunakan dua model regresi dengan variabel dummy, yaitu model dengan tren stokastik dan deterministik. Model

$$
\begin{aligned}
y_{t}= & 87.051 .656-20.7847 V_{1}-622.9890 V_{2}-28.568 .295 V_{3}-48.368 .103 V_{4} \\
& -2.757 .5850 V_{5}+138.198 .508 V_{6}+77.380 .949 V_{7}-42.938 .903 V_{8} \\
& -54.832 .098 V_{9}-61.173 .114 V_{10}-37.492 .672 V_{11}
\end{aligned}
$$

regresi variabel dummy dengan menggunakan tren stokastik adalah sebagai berikut.

Model regresi variabel dummy dengan menggunakan tren deterministik adalah sebagai berikut.

$$
\begin{aligned}
y_{t}= & 87.051 .656-381.001 t-4.398 .858 V_{1}-10.039 .900 V_{2}-31.997 .304 V_{3} \\
& -51.416 .111 V_{4}-30.242 .857 V_{5}+135.912 .502 V_{6}+75.475 .944 V_{7} \\
& -44.462 .907 V_{8}-55.975 .101 V_{9}-61.935 .116 V_{10}-37.873 .673 V_{11}
\end{aligned}
$$

Dari kedua model regresi variabel dummy di atas maka didapatkan nilai residual yang akan digu- nakan dalam permodelan menggunakan model ARIMA pada langkah berikutnya. 
2. Model ARIMA data residual hasil regresi variabel dummy

Residual dari hasil model regresi variabel dummy dengan tren stokastik dan tren deterministik digunakan dalam permodelan ARIMA. Adapun tahap-tahap yang dilakukan dalam permodelan ARIMA adalah sebagai berikut.

\section{a. Uji stasioner}

Untuk melakukan peramalan dengan menggunakan model ARIMA, terlebih dahulu harus dilakukan uji stasioner. Uji stasioner dilakukan untuk melihat apakah data sudah stasioner. Uji dilakukan dengan melihat nilai lambda pada uji Box-Cox untuk stasioner dalam variansi dan melihat nilai Augmented Dickey-Fuller untuk stasioner dalam rata-rata.

Nilai lambda yang didapatkan pada uji Box-Cox untuk model regresi dengan tren stokastik adalah sebesar $-0,127$ dan nilai lambda untuk model regresi dengan tren deterministik adalah sebesar $-0,370$. Hal ini menunjukkan bahwa data penelitian tidak stasioner dalam varian sehingga perlu ditransformasi dengan menggunakan transformasi eksponensial. Setelah data ditransformasi menggunakan transformasi eksponensial $-0,087$ untuk tren stokastik dan eksponensial $-0,450$ untuk tren deterministik, nilai lambda untuk model regresi dengan tren stokastik dan

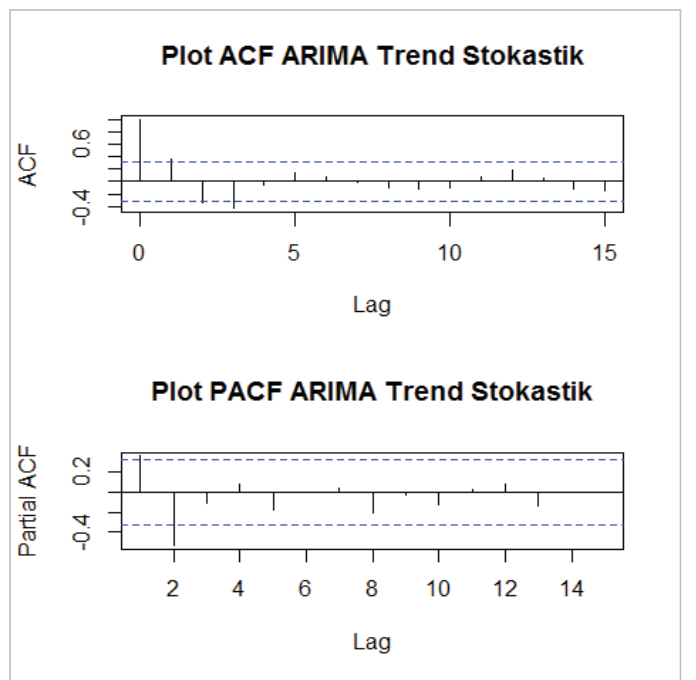

deterministik masing-masing meningkat menjadi sebesar 0,980 dan 0,981 . Hal ini menunjukkan bahwa data penelitian setelah ditransformasi telah stasioner dalam variansi karena memiliki nilai lambda yang sudah mendekati nilai 1.

Tabel 5 menyajikan hasil uji stasioner dalam rata-rata menggunakan uji Augmented Dickey-Fuller.

Tabel 5. Uji Augmented Dickey-Fuller Tren stokastik

\begin{tabular}{lll}
\hline \multirow{2}{*}{ Keterangan } & Tren & \\
\cline { 2 - 3 } & Stokastik & Determinstik \\
\hline Dickey-Fuller & $-4,032$ & $-4,404$ \\
Lag Order & 3 & 3 \\
& 0,019 & 0,010 \\
\hline
\end{tabular}

Tabel 5 menunjukkan bahwa nilai p-value uji Augmented Dickey-Fuller untuk tren stokastik dan deterministik masingmasing adalah sebesar 0,019 dan 0,010. Kedua nilai $p$-value tersebut lebih kecil dari pada $(0,05)$ sehingga dapat disimpulkan bahwa residual dari kedua model regresi tersebut sudah stasioner dalam rata-rata.

b. Identifikasi model ARIMA residual regresi variabel dummy

Identifikasi model ARIMA residual regresi variabel dummy dilakukan dengan melihat plot ACF dan PACF. Adapun plot ACF dan PACF untuk residual dari kedua model regresi tersebut ditampilkan pada Gambar 1.

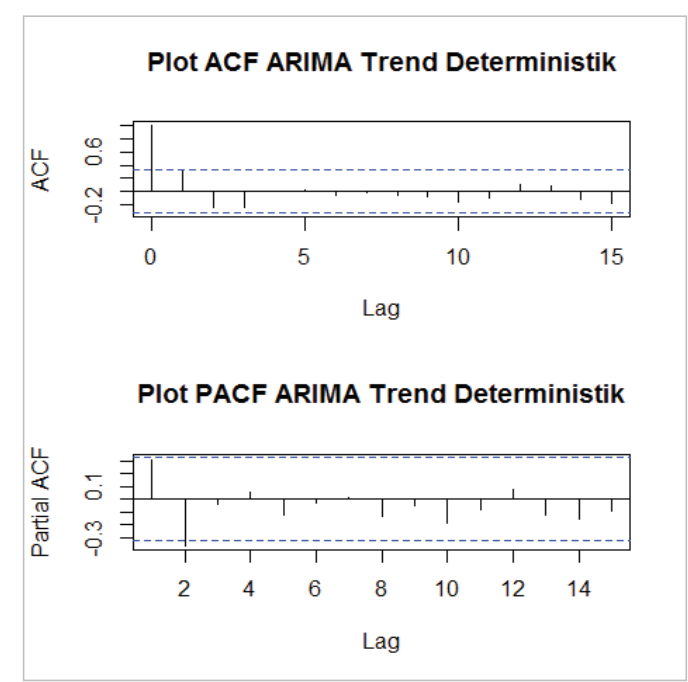

Gambar 1. Plot ACF dan PACF Tren Stokastik dan Deterministik 
Gambar 1 menunjukkan bahwa plot ACF untuk tren stokastik terpotong pada lag pertama, kedua dan ketiga, sedangkan plot PACF terpotong pada lag kedua. Dengan demikian, beberapa model ARIMA yang sesuai untuk tren stokastik tersebut adalah sebagai berikut: $\operatorname{ARIMA}(2,0,1)$, $\operatorname{ARIMA}(2,0,2), \operatorname{ARIMA}(2,0,3)$ dan ARI$\operatorname{MA}(1,0,3)$. Sementara untuk tren deterministik, plot $\mathrm{ACF}$ terpotong pada lag pertama dan plot PACF terpotong pada lag kedua, sehingga beberapa model ARIMA yang sesuai untuk tren deterministik adalah sebagai berikut: $\operatorname{ARIMA}(1,0,1), \operatorname{ARIMA}(2,0,1)$, $\operatorname{ARIMA}(1,0,2)$ dan $\operatorname{ARIMA}(2,0,2)$.

c. Pengujian diagnostik parameter model ARIMA

Hasil dari pengujian diagnostik parameter model ARIMA dengan uji kecocokan model Ljung-Box-Pierce ditampilkan pada Tabel 6.

Berdasarkan hasil uji kecocokan model Ljung-Box-Pierce pada Tabel 6, diketahui bahwa p-value pengujian kedelapan model ARIMA untuk tren stokastik dan deterministik semuanya lebih besar dari pada $(0,05)$. Dengan demikian, dapat disimpulkan bahwa tidak terdapat autokorelasi pada data residual regresi variabel dummy baik untuk tren stokastik maupun tren deterministik. Dengan kata lain, data residual tersebut telah memenuhi asumsi white noise.

d. Pemilihan model ARIMA terbaik

Pemilihan model ARIMA residual regresi variabel dummy terbaik dapat menggunakan indikator RMSE dan MAPE. Nilai RMSE dan MAPE dari model ARIMA residual regresi variabel dummy dengan tren stokastik dan deterministik ditampilkan pada Tabel 7.

Tabel 7 menunjukkan bahwa model ARIMA dengan tren stokastik yang memiliki nilai indikator RMSE dan MAPE terkecil adalah model ARIMA(2,0,3). Sementara untuk model ARIMA dengan tren deterministik, model ARIMA dengan nilai RMSE dan MAPE terkecil adalah model ARIMA(2,0,2). Kedua model dengan nilai kesalahan peramalan terkecil tersebut merupakan model ARIMA terbaik masing-masing untuk residual dari model regresi dengan tren stokastik dan stokastik. Orde dari kedua model ARIMA tersebut digunakan pada proses peramalan dengan model ARIMAX.

Tabel 6. Uji Ljung-Box-Pierce Model ARIMA Tren Stokastik dan Deterministik

\begin{tabular}{lcclll}
\hline Model & \multicolumn{2}{c}{ Tren Stokastik } & & & \multicolumn{2}{l}{ Tren Deterministik } \\
\cline { 5 - 6 } & Chi-Square & p-value & & Chi-Square & p-value \\
\hline ARIMA(2,0,1) & 0,1381 & 0,7102 & & 0,1140 & 0,7356 \\
ARIMA(2,0,2) & 0,0020 & 0,9646 & & 0,5949 & 0,4405 \\
ARIMA(2,0,3) & 0,0364 & 0,8487 & & 0,0122 & 0,9119 \\
ARIMA $(1,0,3)$ & 0,0168 & 0,8967 & & 0,0729 & 0,7872 \\
\hline
\end{tabular}

Tabel 7. Model ARIMA dengan Tren Stokastik Terbaik

\begin{tabular}{|c|c|c|c|}
\hline Tren & Model & RMSE & MAPE \\
\hline \multirow{4}{*}{ Stokastik } & $\operatorname{ARIMA}(2,0,1)$ & 0,0250 & 9,13 \\
\hline & $\operatorname{ARIMA}(2,0,2)$ & 0,0199 & 6,86 \\
\hline & $\operatorname{ARIMA}(2,0,3)^{*}$ & 0,0197 & 6,81 \\
\hline & $\operatorname{ARIMA}(1,0,3)$ & 0,0198 & 6,86 \\
\hline \multirow{4}{*}{ Deterministik } & $\operatorname{ARIMA}(1,0,1)$ & 0,0002 & 48,04 \\
\hline & $\operatorname{ARIMA}(2,0,1)$ & 0,0002 & 47,81 \\
\hline & $\operatorname{ARIMA}(1,0,2)$ & 0,0002 & 43,43 \\
\hline & $\operatorname{ARIMA}(2,0,2)^{*}$ & 0,0002 & 43,41 \\
\hline
\end{tabular}

Keterangan: *Model terbaik. 
1. Model ARIMAX variabel respon

Proses peramalan variabel respon berupa realisasi penerimaan zakat di Baitulmal Aceh dengan model ARIMAX menggunakan orde dari model ARIMA residual regresi variabel dummy pada langkah sebelumnya. Proses ini menggunakan data realisasi penerimaan zakat yang sudah ditransformasi dengan menggunakan transformasi eksponensial. Pada langkah sebelumnya, diperoleh bahwa model ARIMA residual hasil regresi variabel dummy terbaik adalah model $\operatorname{ARIMA}(2,0,3)$ untuk tren stokastik dan model ARIMA $(2,0,1)$ untuk tren deterministik.

a. Pemeriksaan pola musiman

Adapun langkah dalam memeriksa ada atau tidaknya pola musiman pada data adalah dengan menggunakan plot ACF dan PACF sebagai berikut.

Pada Gambar 2 terlihat bahwa plot ACF terpotong pada lag pertama dan kedua, sedangkan plot PACF terpotong pada lag pertama. Berdasarkan plot ACF dan PACF tersebut maka model ARIMA musiman yang digunakan adalah model SARIMA $(2,0,3)$ $(\mathrm{p}, \mathrm{d}, \mathrm{q})^{12}$ dan model SARIMA $(2,0,2)(\mathrm{p}, 0, \mathrm{q})^{12}$. Beberapa model yang memungkinkan untuk digunakan pada proses peramalan dengan model ARIMAX adalah SARIMA $(2,0,3)(1,1,2)^{12}$, $\operatorname{SARIMA}(2,0,3)(1,1,1)^{12}, \operatorname{SARIMA}(2,0,3)$ $(0,1,1)^{12}$, SARIMA $(2,0,3)(1,1,0)^{12}$, $\operatorname{SARIMA}(2,0,2)(1,0,2)^{12}, \operatorname{SARIMA}(2,0,2)$ $(1,0,1)^{12}$, SARIMA $(2,0,2)(0,0,1)^{12}$ dan $\operatorname{SARIMA}(2,0,2)(1,0,0)^{12}$.

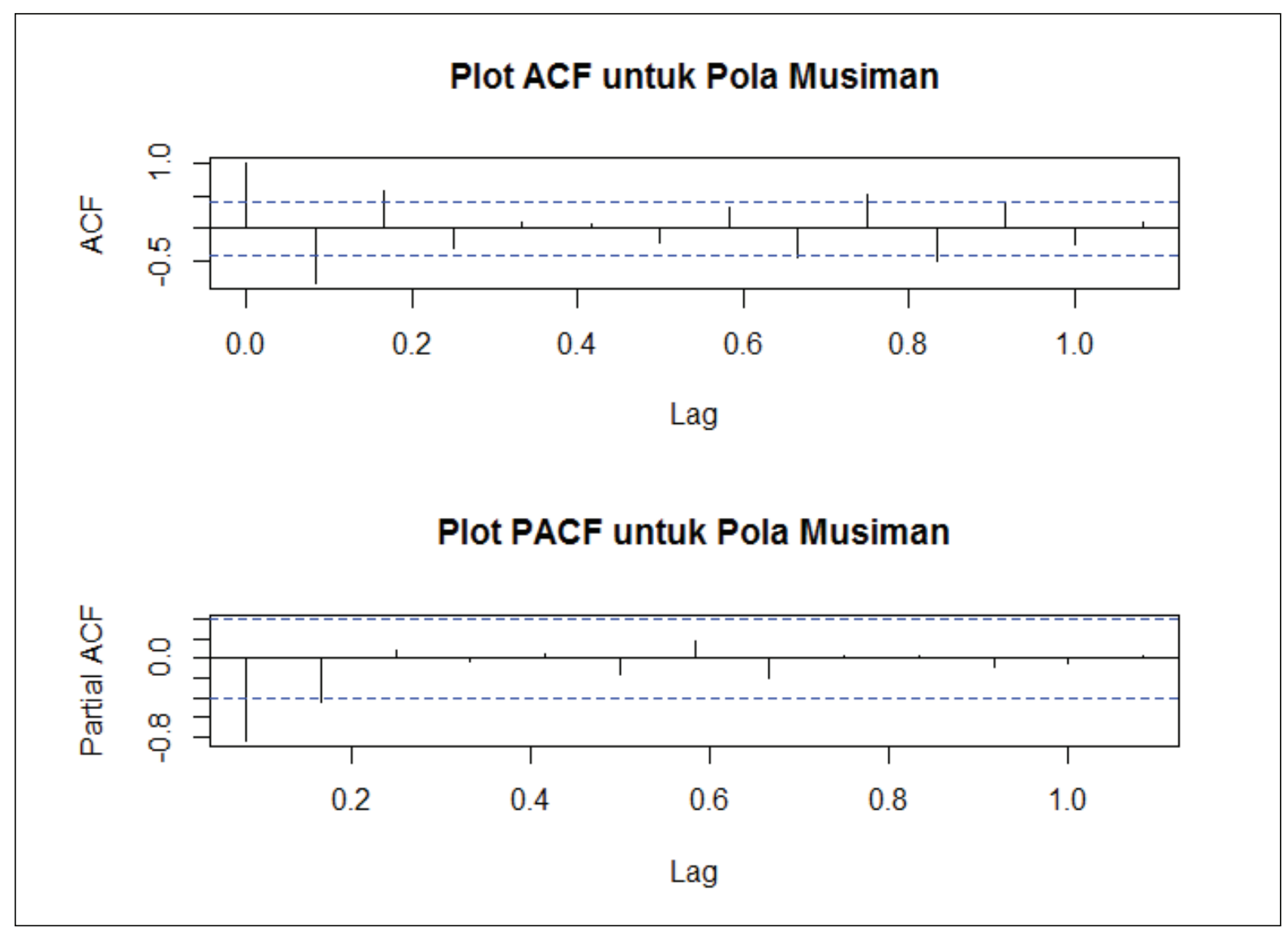

Gambar 2. Plot ACF dan PACF untuk pola musiman 
b. Pengujian diagnostik parameter model ARIMAX

Hasil dari pengujian diagnostik parameter kedelapan model ARIMAX dengan uji kecocokan model Ljung-Box-Pierce ditampilkan pada Tabel 8.

Berdasarkan hasil uji kecocokan model Ljung-Box-Pierce pada Tabel 8, diketahui bahwa seluruh model ARIMAX yang terbentuk memiliki p-value pengujian yang lebih besar dari pada . Oleh karena itu, dapat disimpulkan bahwa tidak terdapat autokorelasi pada residual, sehingga residual telah memenuhi asumsi white noise.

c. Pemilihan model ARIMAX terbaik

Proses pemilihan model ARIMAX terbaik juga dapat menggunakan indikator RMSE dan MAPE. Nilai indikator RMSE dan MAPE model ARIMAX untuk tren stokastik maupun deterministik ditampilkan pada Tabel 9.

Meskipun terdapat beberapa kemungkinan model ARIMAX untuk tren stokastik maupun deterministik, hanya satu model terbaik yang akan digunakan untuk meramalkan realisasi penerimaan zakat untuk tahun 2018 dan 2019. Model terbaik tersebut adalah model yang memiliki nilai indikator RMSE dan MAPE terkecil. Tabel 9 menunjukkan bahwa model ARIMAX dengan tren deterministik ARIMA $(2,0,2)(1,0,2)^{12}$, merupakan model yang memiliki nilai RMSE dan MAPE terkecil dibandingkan dengan model yang lainnya pada tabel tersebut. Model ARIMAX terbaik tersebut akan digunakan untuk meramalkan realisasi penerimaan zakat pada Baitulmal Aceh untuk tahun 2018 dan 2019. Hasil peramalan realisasi penerimaan zakat pada Baitulmal Aceh tersebut disajikan pada Gambar 5 dan Tabel 15.

Tabel 8. Uji kecocokan model Ljung-Box-Pierce ARIMAX

\begin{tabular}{|c|c|c|c|}
\hline Model & Chi-Square & p-value & Keterangan \\
\hline $\operatorname{ARIMA}(2,0,3)(1,1,2)^{12}, \mathrm{~V}_{1,}, \cdot, \mathrm{V}_{11}$ & 0,0074 & 0,9317 & Stokastik \\
\hline $\operatorname{ARIMA}(2,0,3)(1,1,1)^{12}, \mathrm{~V}_{1, \cdots}, \mathrm{V}_{11}$ & 0,0000 & 0,9992 & Stokastik \\
\hline $\operatorname{ARIMA}(2,0,3)(0,1,1)^{12}, \mathrm{~V}_{1, \cdots}, \cdot \mathrm{V}_{11}$ & 0,0040 & 0,9494 & Stokastik \\
\hline $\operatorname{ARIMA}(2,0,3)(1,1,0)^{12}, \mathrm{~V}_{1, \ldots}, \mathrm{V}_{11}$ & 0,0028 & 0,9575 & Stokastik \\
\hline $\operatorname{ARIMA}(2,0,2)(1,0,2)^{12}, \mathrm{t}, \mathrm{V}_{1,}, ., \mathrm{V}_{11}$ & 0,0000 & 0,9973 & Deterministik \\
\hline $\operatorname{ARIMA}(2,0,2)(1,0,1)^{12}, \mathrm{t}, \mathrm{V}_{1,}, \ldots, \mathrm{V}_{11}$ & 0,0000 & 0,9944 & Deterministik \\
\hline $\operatorname{ARIMA}(2,0,2)(0,0,1)^{12}, \mathrm{t}, \mathrm{V}_{1, \ldots}, \mathrm{V}_{11}$ & 0,0048 & 0,9449 & Deterministik \\
\hline $\operatorname{ARIMA}(2,0,2)(1,0,0)^{12}, \mathrm{t}, \mathrm{V}_{1, \cdots}, \ldots, \mathrm{V}_{11}$ & 0,0012 & 0,9726 & Deterministik \\
\hline
\end{tabular}

Tabel 9. Pemilihan model terbaik ARIMAX

\begin{tabular}{|c|c|c|c|}
\hline Model & RMSE & MAPE & Keterangan \\
\hline $\operatorname{ARIMA}(2,0,3)(1,1,2)^{12}, \mathrm{~V}_{1} \ldots, \mathrm{V}_{11}$ & $2,8 \times 10^{7}$ & 20,44 & Stokastik \\
\hline $\operatorname{ARIMA}(2,0,3)(1,1,1)^{12}, \mathrm{~V}_{1}, \cdots, \mathrm{V}_{11}$ & $4,3 \times 10^{7}$ & 32,27 & Stokastik \\
\hline $\operatorname{ARIMA}(2,0,3)(0,1,1)^{12}, \mathrm{~V}_{1, \cdots}, \mathrm{V}_{11}$ & $5 \times 10^{7}$ & 37,68 & Stokastik \\
\hline $\operatorname{ARIMA}(2,0,3)(1,1,0)^{12}, \mathrm{~V}_{1, \ldots, \mathrm{V}_{11}}$ & $5 \times 10^{7}$ & 37,77 & Stokastik \\
\hline $\operatorname{ARIMA}(2,0,2)(1,0,2)^{12}, \mathrm{t}, \mathrm{V}_{1,, . ., \mathrm{V}_{11}} *$ & $2,1 \times 10^{7}$ & 12,72 & Deterministik \\
\hline $\operatorname{ARIMA}(2,0,2)(1,0,1)^{12}, \mathrm{t}, \mathrm{V}_{1, \cdots}, \ldots, \mathrm{V}_{11}$ & $3 \times 10^{7}$ & 18,78 & Deterministik \\
\hline $\operatorname{ARIMA}(2,0,2)(0,0,1)^{12}, \mathrm{t}, \mathrm{V}_{1} \ldots, \mathrm{V}_{11}$ & $4,1 \times 10^{7}$ & 23,01 & Deterministik \\
\hline $\operatorname{ARIMA}(2,0,2)(1,0,0)^{12}, \mathrm{t}, \mathrm{V}_{1}, \cdots, \mathrm{V}_{11}$ & $4 \times 10^{7}$ & 29,97 & Deterministik \\
\hline
\end{tabular}

Keterangan: *Model terbaik. 


\section{B. Peramalan Dengan Model SARIMA}

Proses peramalan dengan model SARIMA meliputi langkah-langkah sebagai berikut.Uji stasioner

Untuk melakukan permodelan dengan menggunakan model SARIMA, terlebih dahulu harus dilakukan uji stasioner. Uji stasioner dilakukan untuk melihat apakah data sudah stasioner atau belum. Uji dilakukan dengan melihat nilai lambda pada uji Box-Cox untuk stasioner dalam variansi dan melihat nilai Augmented Dickey-Fuller untuk stasioner dalam rata-rata.

Pengujian Box-Cox untuk data penelitian menghasilkan nilai lambda sebesar -0,999. Hal ini menunjukkan bahwa data tidak stasioner pada varian sehingga data perlu ditransformasi dengan menggunakan transformasi logaritma. Setelah dilakukan transformasi data dengan menggunakan transformasi logaritma, terjadi peningkatan nilai lambda menjadi sebesar 1,099 yang mengindikasikan bahwa data setelah transformasi telah stasioner dalam variansi karena sudah mendekati 1.
Tabel 10 menyajikan hasil uji stasioner dalam rata-rata menggunakan uji Augmented Dickey-Fuller.

Tabel 10 menunjukkan bahwa $p$-value pengujian Augmented Dickey-Fuller untuk data asli adalah sebesar 0,09 . Hal ini mengindikasikan bahwa data yang digunakan belum stasioner terhadap rata-rata. Sehingga perlu dilakukan proses differencing terhadap data tersebut. Setelah dilakukan differencing, nilai $p$-value pegujian Augmented Dickey-Fuller menjadi lebih kecil dari pada 0,05 yang menunjukkan bahwa data setelah differencing telah stasioner terhadap rata-rata.

2. Identifikasi model ARIMA

Identifikasi model ARIMA dilakukan dengan melihat plot ACF dan PACF pada Gambar 3.

Gambar 3 menunjukkan bahwa plot ACF terpotong pada lag pertama dan plot PACF terpotong pada lag ketiga. Beberapa model yang dapat diidentifikasi berdasarkan plot ACF dan PACF tersebut adalah $\operatorname{ARIMA}(3,1,0)$, $\operatorname{ARIMA}(2,1,0)$, ARIMA $(0,1,3)$ dan $\operatorname{ARIMA}(0,1,2)$.

Tabel 10. Uji Augmented Dickey-Fuller Model SARIMA

\begin{tabular}{lcc}
\hline \multirow{2}{*}{ Keterangan } & \multicolumn{2}{c}{ Model } \\
\cline { 2 - 3 } & Data asli & Data differencing \\
\hline Dickey-Fuller & $-3,284$ & $-5,416$ \\
Lag Order & 3 & 3 \\
-value & 0,09 & 0,01 \\
\hline
\end{tabular}

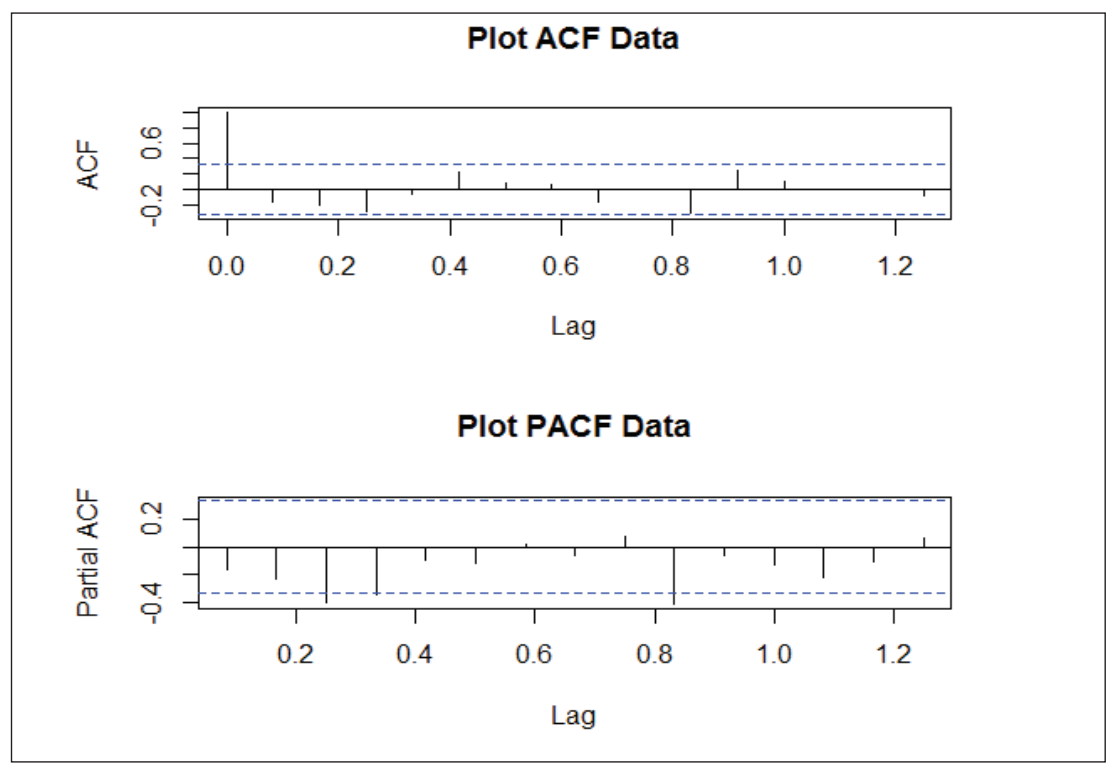

Gambar 3. Plot ACF dan PACF Model ARIMA 
3. Pengujian diagnostik parameter model ARIMA

Hasil dari pengujian diagnostik parameter keempat model ARIMA dengan uji kecocokan model Ljung-Box-Pierce ditampilkan pada Tabel 11.

Tabel 11 menunjukkan bahwa nilai $p$-value pengujian Ljung-Box-Pierce untuk keempat model ARIMA yang telah diidentifikasi tersebut bernilai lebih besar dari pada 0,05 . Hal ini menunjukkan bahwa residual model ARIMA tidak memiliki masalah autokorelasi atau dengan kata lain residual telah memenuhi asumsi white noise.

4. Pemilihan model ARIMA terbaik

Pemilihan model ARIMA terbaik didasarkan pada indikator RMSE dan MAPE. Nilai RMSE dan MAPE dari keempat model ARIMA ditampilkan pada Tabel 12.

Tabel 12 menunjukkan bahwa model ARIMA yang memiliki nilai indikator RMSE dan MAPE

Tabel 11. Uji Ljung-Box-Pierce Model ARIMA

\begin{tabular}{lcc}
\hline Model & Chi-Square & p-value \\
\hline $\operatorname{ARIMA}(3,1,0)$ & 0,4982 & 0,4803 \\
$\operatorname{ARIMA}(2,1,0)$ & 0,3118 & 0,5766 \\
$\operatorname{ARIMA}(0,1,3)$ & 0,0154 & 0,9012 \\
$\operatorname{ARIMA}(0,1,2)$ & 0,0510 & 0,8213 \\
\hline
\end{tabular}

terkecil adalah model $\operatorname{ARIMA}(0,1,2)$. Dengan demikian, model ARIMA $(0,1,2)$ merupakan model ARIMA terbaik yang akan digunakan dalam proses pembentukan model SARIMA.

5. Pemeriksaan pola musiman

Sama halnya dengan identifikasi model ARIMA, identifikasi model SARIMA juga didasarkan pada plot ACF dan PACF untuk memeriksa pola musiman pada data. Gambar 4 menampilkan plot ACF dan PACF untuk pola musiman.

Pada Gambar 4 terlihat bahwa plot ACF terpotong pada lag pertama dan kedua, sedangkan pada plot PACF terpotong pada lag pertama. Berdasarkan plot ACF dan PACF tersebut, maka dapat diidentifikasi beberapa model SARIMA yang dapat digunakan antara lain SARIMA $(0,1,2)(1,1,0)^{12}, \operatorname{SARIMA}(0,1,2)$ $(1,1,1)^{12}$, SARIMA $(0,1,2)(1,1,2)^{12}$ dan SARIMA $(0,1,2)(0,1,1)^{12}$.

Tabel 12. Identifikasi Model ARIMA Terbaik

\begin{tabular}{lcc}
\hline Model & RMSE & MAPE \\
\hline ARIMA(3,1,0) & 89.230 .503 & 106,18 \\
ARIMA $(2,1,0)$ & 93.206 .296 & 113,69 \\
ARIMA $(0,1,3)$ & 75.006 .742 & 97,05 \\
ARIMA $(0,1,2)^{*}$ & 74.567 .793 & 94,03 \\
\hline
\end{tabular}

Keterangan: *Model terbaik.

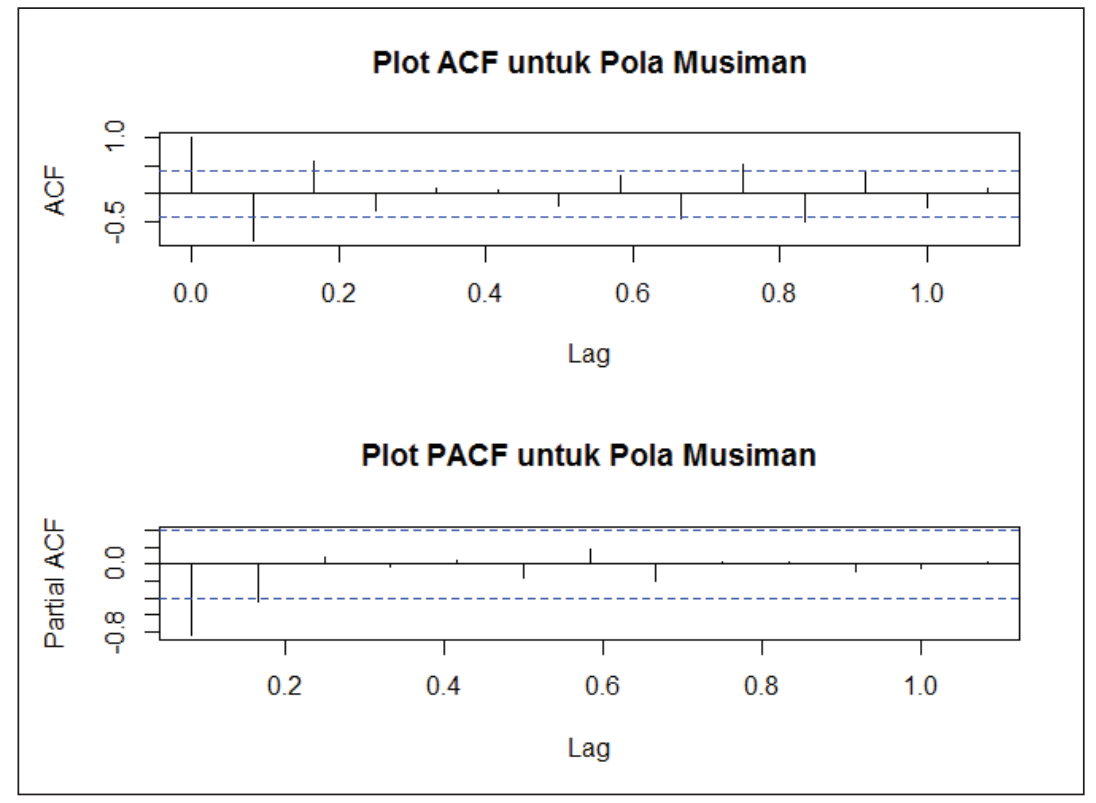

Gambar 4. Plot ACF dan PACF untuk pola musiman 
6. Pengujian diagnostik parameter model SARIMA

Tabel 13 menyajikan hasil pengujian diagnostik parameter dengan uji kecocokan model Ljung-Box-Pierce untuk keempat model SARIMA yang telah diidentifikasi pada langkah sebelumnya.

Tabel 13 menunjukkan bahwa keempat model SARIMA yang diujikan telah memiliki nilai $p$-value yang lebih besar dari pada 0,05 . Hal ini menunjukkan bahwa tidak terdapatnya autokorelasi pada residual dari keempat model SARIMA tersebut dan telah memenuhi asumsi white noise.

7. Pemilihan model SARIMA terbaik

Dari keempat model SARIMA tersebut, selanjutnya akan dipilih model terbaik yang akan digunakan untuk meramalkan realisasi penerimaan zakat di Baitulmal Aceh. Pemilihan model ARIMA terbaik juga

Tabel 13. Uji Ljung-Box-Pierce model SARIMA

\begin{tabular}{lcc}
\hline Model & Chi-Square & $\boldsymbol{p}$-value \\
\hline $\operatorname{ARIMA}(0,1,2)(1,1,0)^{12}$ & 0,0794 & 0,7782 \\
$\operatorname{ARIMA}(0,1,2)(1,1,1)^{12}$ & 0,0793 & 0,7782 \\
$\operatorname{ARIMA}(0,1,2)(1,1,2)^{12}$ & 0,0789 & 0,7788 \\
$\operatorname{ARIMA}(0,1,2)(0,1,1)^{12}$ & 0,0793 & 0,7782 \\
\hline
\end{tabular}

didasarkan pada indikator RMSE dan MAPE. Nilai RMSE dan MAPE dari keempat model SARIMA tersebut ditampilkan pada Tabel 14.

Tabel 14 menunjukkan bahwa model SARIMA yang memiliki nilai indikator RMSE dan MAPE terkecil adalah model ARIMA $(0,1,2)$ $(0,1,1)^{12}$. Model SARIMA tersebut akan digunakan dalam proses peramalan realisasi penerimaan zakat pada Baitulmal Aceh untuk tahun 2018 dan 2019. Hasil peramalan realisasi penerimaan zakat pada Baitulmal Aceh dengan model SARIMA terbaik tersebut disajikan pada Gambar 5 dan Tabel 15.

\section{Peramalan Realisasi Penerimaan Zakat Baitulmal Aceh Tahun 2018 dan 2019}

Peramalan realisasi penerimaan zakat bulanan untuk tahun 2018 dan 2019 dengan menggunakan model ARIMAX dan SARIMA terbaik dapat dilihat pada Gambar 5 .

Tabel 14. Identifikasi Model SARIMA Terbaik

\begin{tabular}{lcc}
\hline Model & RMSE & MAPE \\
\hline ARIMA $(0,1,2)(1,1,0)^{12}$ & 63.282 .135 & 50,18 \\
ARIMA $(0,1,2)(1,1,1)^{12}$ & 63.282 .108 & 50,18 \\
ARIMA $(0,1,2)(1,1,2)^{12}$ & 63.285 .806 & 50,19 \\
ARIMA $(0,1,2)(0,1,1)^{12 *}$ & 63.282 .012 & 50,18 \\
\hline
\end{tabular}

Keterangan: *Model terbaik.

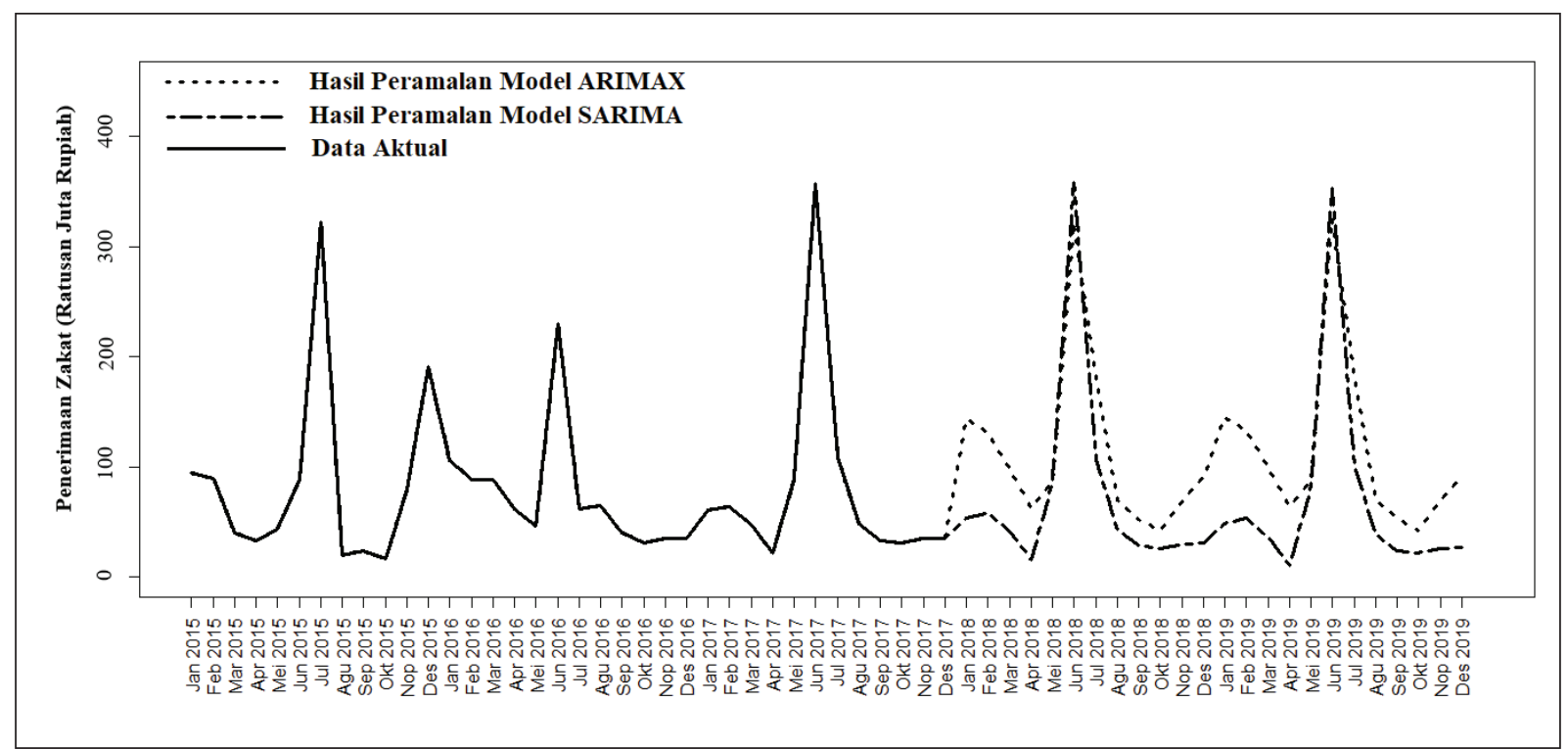

Sumber: Baitulmal Aceh (2018), diolah.

Gambar 5. Plot peramalan realisasi penerimaan zakat Baitulmal Aceh tahun 2018 dan 2019 
Gambar 5 menampilkan data aktual dan hasil peramalan realisasi penerimaan zakat Baitulmal Aceh. Garis tanpa putus yang berwarna hitam merupakan data aktual realisasi penerimaan zakat Baitulmal Aceh tahun 2015 - 2017, garis titik-titik merupakan hasil peramalan realisasi penerimaan zakat dari model ARIMA $(2,0,2)(1,0,2)^{12}$, dan garis putus-putus merupakan hasil peramalan dari model ARIMA $(0,1,2)(0,1,1)^{12}$. Secara umum, hasil peramalan realisasi penerimaan zakat yang ditampilkan pada Gambar 5 menunjukkan bahwa pola nilai peramalan tersebut cenderung mengikuti pola data sebelumnya. Hal ini mengindikasikan adanya efek variasi kalender dalam hasil peramalan realisasi penerimaan zakat tersebut. Adapun nilai peramalan realisasi penerimaan zakat bulanan pada Batiul Mal Aceh dengan menggunakan model ARIMAX dan SARIMA terbaik dapat dilihat pada Tabel 15.

Tabel 15. Hasil peramalan realisasi zakat Baitulmal Aceh periode Januari 2018 - Desember 2019

\begin{tabular}{lccc}
\hline \multicolumn{1}{c}{ Bulan/Tahun } & $\begin{array}{c}\text { Realisasi Penerimaan Zakat } \\
\text { (Rp.) } \\
\text { Model ARIMAX }\end{array}$ & Bulan/Tahun & $\begin{array}{c}\text { Realisasi Penerimaan Zakat } \\
\text { (Rp.) } \\
\text { Model SARIMA }\end{array}$ \\
\hline Januari/2018 & 143.983 .500 & Januari/2018 & 53.050 .878 \\
Februari/2018 & 131.836 .111 & Februari/2018 & 58.377 .055 \\
Maret/2018 & 97.311 .451 & Maret/2018 & 40.996 .455 \\
Apri1/2018 & 63.001 .156 & April/2018 & 15.038 .124 \\
Mei/2018 & 86.771 .827 & Mei/2018 & 86.690 .797 \\
Juni/2018 & 321.415 .171 & Juni/2018 & 358.414 .633 \\
Juli/2018 & 180.041 .503 & Juli/2018 & 106.392 .943 \\
Agustus/2018 & 69.492 .985 & Agustus/2018 & 42.728 .456 \\
September/2018 & 52.623 .502 & September/2018 & 28.582 .222 \\
Oktober/2018 & 41.726 .954 & Oktober/2018 & 26.143 .629 \\
November/2018 & 69.153 .724 & November/2018 & 30.212 .682 \\
Desember/2018 & 90.168 .620 & Desember/2018 & 31.047 .339 \\
Januari/2019 & 145.287 .261 & Januari/2019 & 48.333 .673 \\
Februari/2019 & 133.029 .879 & Februari/2019 & 53.700 .132 \\
Maret/2019 & 98.192 .600 & Maret/2019 & 36.319 .532 \\
April/2019 & 63.571 .628 & April/2019 & 10.361 .202 \\
Mei/2019 & 87.557 .540 & Mei/2019 & 82.013 .874 \\
Juni/2019 & 324.325 .564 & Juni/2019 & 353.737 .710 \\
Juli/2019 & 181.671 .767 & Juli/2019 & 101.716 .020 \\
Agustus/2019 & 70.122 .239 & Agustus/2019 & 38.051 .534 \\
September/2019 & 53.100 .005 & Noptember/2019 & 23.905 .299 \\
Oktober/2019 & 42.104 .788 & 21.466 .706 \\
November/2019 & 69.779 .906 & 25.535 .759 \\
Desember/2019 & 90.985 .091 & 26.370 .417 \\
\hline & &
\end{tabular}


Tabel 15 menunjukkan bahwa realisasi penerimaan zakat tertinggi yang mungkin dikumpulkan oleh Baitulmal Aceh berdasarkan model ARIMAX diperkirakan terjadi pada bulan Juni tahun 2019 dengan estimasi nilai sebesar Rp. 324.325.564. Sementara itu, realisasi penerimaan zakat tertinggi berdasarkan model SARIMA diperkirakan terjadi pada bulan Juni tahun 2018 dengan dana yang dikumpulkan diestimasi sebesar Rp. 353.737.710. Hal ini kemungkinan terjadi karena bulan Juni tahun 2018 bertepatan dengan bulan suci ramadan 1439 H. Sebaliknya, realisasi penerimaan zakat terendah yang dikumpulkan oleh badan amil dari muzakki (orang yang mengeluarkan zakat) untuk model ARIMAX diperkirakan terjadi pada bulan Oktober tahun 2018 dengan dana yang dikumpulkan diestimasi sebesar Rp. 41.727.062. Sementara untuk model SARIMA, realisasi penerimaan zakat terendah diperkirakan terjadi pada bulan Oktober tahun 2019 dengan dana yang terkumpul diperkirakan sebesar Rp. 21.466.706.

Meskipun kedua model menghasilkan nilai peramalan yang berbeda, analisis terhadap indikator tingkat kesalahan hasil peramalan berupa RMSE dan MAPE menunjukkan bahwa model peramalan ARIMAX memiliki tingkat akurasi peramalan yang jauh lebih baik dari pada model SARIMA. Oleh karena itu, model ARIMAX dipilih sebagai model terbaik dalam meramalkan realisasi penerimaan zakat pada Baitulmal Aceh. Dengan demikian, total realisasi penerimaan zakat pada Baitulmal Aceh pada tahun 2018 dan 2019 berdasarkan model ARIMAX terbaik masing-masing diperkirakan sebesar Rp. 1.347.526.504 dan Rp. 1.359.728.268.

Jumlah penerimaan zakat yang terkumpul sangat tergantung pada jumlah muzaki yang mengeluarkan zakat melalui Baitulmal. Menurut Sardiana dan Zulfison (2018)Infaq, Shadaqah and Endowments (ZISWAF, literasi keuangan syariah yang dibentuk oleh pengetahuan, kemampuan, dan sikap atau keyakinan mempengaruhi masyarakat dalam mengalokasikan dananya untuk mengeluarkan zakat, infak dan sedekah (ZIS). Potensi zakat nasional secara keseluruhan mencapai 19,3 triliun (Sumadi, 2017). Menurut Mashudi (2015), potensi zakat yang sangat besar tersebut juga harus diimbangi dengan pengelolaan zakat yang professional. Oleh karena itu, diperlukan suatu lembaga khusus yang mampu mengelola zakat tersebut secara profesional, transparan, kredibel, dan amanah (Anwar et al., 2017). Beberapa studi menunjukkan bahwa pengelolaan zakat yang baik dapat mengurangi jumlah dan persentase penduduk miskin, serta mengurangi kedalaman dan tingkat keparahan kemiskinan (Masruroh dan Farid, 2019; Romdhoni, 2017). Dengan demikian, semakin banyak dana ZIS yang terkumpulkan oleh Baitulmal Aceh, maka akan semakin besar efeknya terhadap pengurangan angka kemiskinan di Provinsi Aceh terutama pada mereka yang berhak menerima zakat (mustahik). Zakat dapat mengurangi jarak atau kesenjangan antara orang yang berada dengan orang lain yang kurang beruntung (Sa'adah, 2017).

Tidak dapat dipungkiri bahwa masih banyak muzaki yang mengelurkan zakatnya melalui lembaga zakat informal. Menurut Yughi (2019), terdapat 5 faktor individu yang mempengaruhi muzakki dalam membayar zakat mereka ke lembaga zakat informal yaitu (1) faktor keimanan, kesadaran individu, dan sosial, (2) religiusitas, (3) pengetahuan zakat, (4) kepuasan diri dan (5) penghargaan dan kompensasi. Pemerintah daerah Provinsi Aceh diharapkan dapat menggandeng lembaga zakat informal tersebut sebagai partner dalam pengelolaan zakat di Provinsi Aceh sehingga program-program yang telah disiapkan melalui Baitulmal Aceh dapat dilaksanakan secara lebih optimal pada masa yang akan datang. Selain itu, diperlukan upaya aktif dari Baitulmal dalam upaya mengumpulkan dana zakat dari muzakki. Beberapa strategi yang dapat diterapkan oleh Baitulmal antara lain datang langsung ke tempat calon nasabah, melakukan promosi melalui brosur, spanduk, baliho serta media sosial, dan strategi peduli masyarakat yang diterapkan dalam kegiatan amal/sosial (Sanwani et al., 2017).

\section{KESIMPULAN DAN SARAN}

Peramalan potensi penerimaan zakat merupakan hal yang penting bagi Baitulmal Aceh. Model ARIMAX dengan orde ARIMA $(2,0,2)(1,0,2)^{12}$, $\mathrm{t}, \mathrm{V}_{1}, \ldots, \mathrm{V}_{11}$ memberikan hasil peramalan realisasi penerimaan zakat yang lebih akurat jika dibandingkan dengan model SARIMA dengan 
orde ARIMA $(0,1,2)(0,1,1)^{12}$. Total penerimaan zakat pada Baitulmal Aceh untuk tahun 2018 dan 2019 secara berurutan diperkirakan sebesar Rp. 1.347.526.504 dan Rp. 1.359.728.268. Baitulmal Aceh dapat menggunakan informasi tersebut sebagai salah satu rujukan dalam penyusunan program pendistribusian zakat pada masa yang akan datang. Selain itu, Baitulmal Aceh disarankan untuk mengambil langkahlangkah aktif dalam upaya meningkatkan angka realisasi penerimaan zakat di Provinsi Aceh, sehingga manfaatnya dapat dirasakan oleh lebih banyak penerima zakat (mustahik). Salah satu keterbatasan penelitian ini berkaitan dengan jumlah periode data yang relatif sedikit. Meskipun demikian, model ARIMAX dengan mempertimbangkan efek dari variasi kalender mampu memberikan hasil peramalan yang jauh lebih akurat dari pada model SARIMA sebagai model pembanding.

\section{DAFTAR PUSTAKA}

Al-Qardhawi, Y. (2007). Fiqh al-Zakah. Beirut: Muassasah Al-Risalah.

Andrews, B. H., Dean, M. D., Swain, R., \& Cole, C. R. F. (2013). Building ARIMA and ARIMAX Models for Predicting Long-Term Disability Benefit Application Rates in the Public/Private Sectors. In Society of Actuaries Health Section (pp. 1-54). Society of Actuaries.

Anggraeni, W., Vinarti, R. A., \& Kurniawati, Y. D. (2015). Performance Comparisons between Arima and Arimax Method in Moslem Kids Clothes Demand Forecasting: Case Study. Procedia Computer Science, 72, 630-637. https://doi.org/10.1016/J. PROCS.2015.12.172

Anwar, S. (2017). Peramalan Suhu Udara Jangka Pendek di Kota Banda Aceh dengan Metode Autoregressive Integrated Moving Average (ARIMA). Malikussaleh Journal of Mechanical Science and Technology, 5(1), 6-12.

Anwar, S., Afriyani, A., Ahya, D., Nurhidayati, N., Iswani, N., Ariska, R., \& Wahyudi, R. (2017). Analisis Faktor yang Mempengaruhi Lama Waktu Pembayaran Angsuran Pertama
Program ZIS Produktif Baitulmal Aceh. Statistika: Journal of Theoretical Statistics and Its Applications, 17(2), 53-61. https:// doi.org/10.29313/jstat.v17i2.2697

Box, G. E. P., \& Cox, D. R. (1964). An Analysis of Transformations. Journal of the Royal Statistical Society. Series B (Methodological), 26(2), 211-252.

Cleveland, W. S., \& Devlin, S. J. (1982). Calendar effects in monthly time series: Modeling and adjustment. Journal of the American Statistical Association, 77(379), 520-528. https://doi.org/10.1080/01621459.1982.10 477841

Cryer, J. D., \& Chan, K.-S. (2008). Time Series Analysis With Applications in $R$ (Second Edition). New York: Springer.

Fitri, M. (2017). Pengelolaan Zakat Produktif sebagai Instrumen Peningkatan Kesejahteraan Umat. Economica: Jurnal Ekonomi Islam, 8(1), 149-173. https://doi. org/10.21580/economica.2017.8.1.1830

Hyndman, R. J., \& Athanasopoulos, G. (2018). Forecasting: Principles and Practice (Second Edition). Victoria: OTexts.

Kongcharoen, C., \& Kruangpradit, T. (2013). Autoregressive Integrated Moving Average with Explanatory Variable (ARIMAX) Model for Thailand Export. In Conference: the 33rd International Symposium on Forecasting (pp. 1-8). Seoul.

Lee, M. H., Suhartono, S., \& Hamzah, N. A. (2010). Calendar Variation Model Based on ARIMAX for Forecasting Sales Data with Ramadhan Effect. In Proceedings of the Regional Conference on Statistical Sciences (pp. 349-361). Malaysia.

Liu, L.-M. (1980). Note—Analysis of Time Series with Calendar Effect. Management Science, 26(1), 106-112.

Liu, L.-M. (2009). Time series analysis and forecasting (Second). River Forest: Scientific Computing Associates Corp.

Makridakis, S., Wheelwright, S. C., \& McGee, V. E. (2000). Metode dan Aplikasi Peramalan. Jakarta: Interaksara. 
Mas'ud, R., \& Muhamad, M. (2005). Zakat \& Kemiskinan: Instrumen Pemberdayaan Ekonomi Umat. Yogyakarta: UII Press.

Mashudi, M. (2015). Urgensi Zakat Dalam Revolusi Mustahik Menjadi Muzakki. Iqtishoduna: Jurnal Ekonomi Islam, 4(1), 38-50.

Masruroh, I., \& Farid, M. (2019). Pengaruh Pengelolaan Ekonomi Produktif dalam Mengentaskan Kemiskinan di Kota Lumajang Studi pada Badan Amil Zakat Nasional (BAZNAS) Kabupaten Lumajang. Iqtishoduna: Jurnal Ekonomi Islam, 8(1), 209-229.

Montgomery, D. C., Jennings, C. L., \& Kulahci, M. (2008). Introduction to Time Series Analysis and Forecasting. New Jersey: John Wiley \& Sons.

Rodin, D. (2015). Pemberdayaan Ekonomi Fakir Miskin Dalam Perspektif Al-Qur'an. Economica: Jurnal Ekonomi Islam, 6(1), 71-102. https://doi.org/10.21580/ economica.2015.6.1.787

Romdhoni, A. H. (2017). Zakat Dalam Mendorong Pertumbuhan Ekonomi dan Pengentasan Kemiskinan. Jurnal Ilmiah Ekonomi Islam, 3(01), 41-51. https://doi.org/10.29040/jiei. v3i01.98
Sa'adah, S. L. (2017). Zakat Wakaf (Ziswa): Solusi dalam Mewujudkan Pemberdayaan Umat. Iqtishoduna: Jurnal Ekonomi Islam, 6(2), 261-283.

Sanwani, S., Herwanti, T., \& Jufri, A. (2017). Strategi Penghimpunan dan Penyaluran Dana pada Baitul Maal Wat Tamwil (BMT) al-Hidayah di Kabupaten Lombok Timur. Iqtishoduna: Jurnal Ekonomi Islam, 6(1), 34-64.

Sardiana, A., \& Zulfison, Z. (2018). Implementasi Literasi Keuangan Syariah Pada Alokasi Dana Ziswaf Masyarakat. Maqdis : Jurnal Kajian Ekonomi Islam, 3(2), 171-180.

Sumadi, S. (2017). Optimalisasi Potensi Dana Zakat, Infaq, Sadaqah Dalam Pemerataan Ekonomi Di Kabupaten Sukoharjo (Studi Kasus di Badan Amil Zakat Daerah Kab. Sukoharjo). Jurnal Ilmiah Ekonomi Islam, 3(01), 16-26. https://doi.org/10.29040/jiei. v3i01.68

Wei, W. W. S. (2006). Time Series Analysis : Univariate and Multivariate Methods (Second Edi). New York: Pearson AddisonWesley.

Yughi, S. A. (2019). Faktor Preferensi Individu Muzakki Lembaga Zakat Informal. Iqtishoduna: Jurnal Ekonomi Islam, 8(1), 156-182. 